\title{
Educational and Wage Risk: Social Insurance vs. Quality of Education
}

\author{
DIRK SCHINDLER \\ BENJAMIN WEIGERT
}

CESIFO WORKING PAPER NO. 2513

CATEGORY 1: PUblic FinANCE

DECEMBER 2008

Presented at CESifo Area Conference on Public Sector Economics, April 2008

\footnotetext{
An electronic version of the paper may be downloaded

- from the SSRN website: www.SSRN.com

- from the RePEc website: - from the CESifo website: 


\title{
Educational and Wage Risk: Social Insurance vs. Quality of Education
}

\begin{abstract}
In this model of education, where individuals are exposed both to educational risk and to wage risk within the skilled sector, successful graduation depends both on individual effort to study and on public resources. We show that insuring the present risks is a dichotomic task: Wage risk is diversified ex post among the skilled by graduate taxation and skill-specific tuition fees. Educational risk of failure and inequality between skilled and unskilled workers are mitigated ex ante by enhancing the quality of education. The necessary expenditures are optimally financed by regressive tuition fees and the net revenue from the graduate tax.

JEL Code: H21, I2, J2.

Keywords: human capital investment, educational risk, wage risk, learning effort, graduate taxation, regressive tuition fees.

\author{
Dirk Schindler \\ University of Konstanz \\ Fach $D 133$ \\ 78457 Konstanz \\ Germany \\ Dirk.Schindler@uni-konstanz.de
}

\author{
Benjamin Weigert \\ Justus-Liebig-University Giessen \\ Department of Economics \\ Licher Strasse 66 \\ Germany-35394 Giessen \\ benjamin.weigert@wirtschaft.uni-giessen.de
}

December 19, 2008

The paper has profited from discussion with Bas Jacobs and Stefan Zink and from valuable suggestions by participants of the CESifo Area Conference on Public Sector Economics in Munich and the IIPF-meeting in Maastricht. 


\section{Introduction}

This paper deals with educational and wage risks and characterizes optimal educational and tax policies to mitigate the effects of wage inequality and skill-biased technological change. Optimal educational policies thereby include regressive (ex ante) tuition fees and graduate taxation as well as public real investment in order to foster the quality of educational institutions (e.g., universities).

At least in the last 20 years, one observes an increasing wage inequality in nearby all developed countries. On the one hand, the wage gap between skilled and unskilled workers is rising and on the other hand there are wage differentials across industries within the skilled sector. These trends in wages are mainly driven by ongoing globalization of the world economy and by skill-biased technological change. ${ }^{1}$ Jacobs (2004) forecasts the wage gap between skilled and unskilled wages to be widening even more, due to a higher growth rate in skilled labor demand relative to skilled labor supply. Skill-biased technological progress does, however, not only harm unskilled workers, it also affects the utilization and depreciation of human capital in different industries in different ways (see, e.g., Wildasin, 2000). This leads to wage uncertainty in the skilled sector and fits to the Mincer (1974)-view of education and human capital investment increasing risk. The results by Mincer (1974) are renewed and backed, e.g., by Carneiro et al. (2003), examining high-school and college graduates and showing the overwhelming part of variance in returns to education to be unpredictable by students at the time of investment.

Taken together, these wage inequalities correspond to educational risk (risk of failure to enter the skilled sector) and to wage risk within the skilled sector, because ex ante it is uncertain which kind of employment one will find. The main difference between these kinds of risk is that for educational risk households and the government determine the probability distribution endogenously by choosing learning effort and educational quality. Hence, ex ante insurance by increasing the success probability (i.e., the quality of education) is possible. This fits to regarding the education system as a 'filter technology' producing ex post heterogeneity

\footnotetext{
${ }^{1}$ See, e.g., Krugman (1995) and Katz and Autor (1999). Another reason for observed wage inequality is seen in increasing educational wage differentials.
} 
and calling for redistribution, even if the playing field is level by full access to education, i.e., if households are homogenous ex ante or if there is equality of opportunities in case of ex ante heterogeneity, see Konrad (2004). For wage risk instead, only the ex post exposure to risk can be affected, but the entry probability for each state of nature is exogenous. In a risk- and inequality-averse society, these two kinds of risk do not only cause inefficient investment in education, ${ }^{2}$ but also give raise to redistributive motives between winners and looser. As private insurance markets seem not to work (see Sinn, 1996) due to, e.g., adverse selection - the good risks are opting out - and legal limitations (students are too young for writing binding contracts), this calls for governmental intervention.

However, what can be done? Is it sufficient to increase population's acquirement of higher education and human capital, as proposed by the EU 'Lisbonagenda' (EU-Council, 2005)? How should this be financed? What happens, if risk of failure and of ending up as unskilled worker is weighed against wage risk of skilled workers? Are ex post income transfers another, a better or an additional way of insurance?

We show that the welfare maximizing governmental revenue policy is characterized by (i) a graduate tax on skilled earned income, (ii) a general lump-sum tax, which can be seen as general tuition fees paid by all households and (iii) by skilled-specific tuition fees, turning most likely into education subsidies to successful students and creating, consequently, a regressive structure of 'frontloaded' tuition fees. A general labor tax is not used. Unskilled workers are net tax payers and tax revenue is spent on investments to enhance the quality of education in order to increase the success probability in educational investment for all households. This provides ex ante insurance and mitigates distortions in learning effort, created by taxation.

These results are derived in a two-period model, where the individuals first decide on their learning effort. This determines their success probability in higher education. At the end of the first period, success risk in education and an industryspecific productivity shock in the skilled sector realize. The latter shock can be seen as technological change, affecting utilization of human capital differently

\footnotetext{
${ }^{2}$ See Levhari and Weiss (1974), who are the first in analyzing these topics, but also Kodde $(1986,1988)$.
} 
across industries. At the beginning of the second period, the individuals observe in which sector respectively in which industry within the skilled sector they will be employed and choose their sector-contingent labor supply. The benevolent government can use a proportional wage tax on all incomes, a graduate tax (being paid only by skilled workers) and skill-specific tuition fees in order to finance both a general lump-sum transfer and public funding of the education system. Public educational spending is assumed to increase the success probability by enhancing the quality in the educational sector and therefore by enhancing the 'filter technology.'

The proceeding is as follows: In the next section, we provide a short overview on related literature. The model is presented in section 3 . Then, we characterize optimal household behavior in section 4 and describe public policy in section 5. In section 6, finally, optimal usage of tax instruments and optimal public investment are derived. Section 7 concludes.

\section{Relationship to the Literature}

There is some literature on optimal tax policy in case of risky human capital investment and wage uncertainty. This paper combines and extends two strands: First, there are models focusing on (pure) wage risk (within one sector), second there are models dealing with success risk in education and the wage differential between a skilled and an unskilled sector.

It is well known from the seminal paper series by Eaton and Rosen (1980a,b) that it is optimal to implement a distorting wage tax, because the insurance provided will outweigh the excess burden, if wage income is subject to (idiosyncratic) risk. Hamilton (1987) confirms this result and extends their model for capital income taxation as indirect education policy. He argues that remaining underinvestment in education is inefficient and calls for education subsidies. In a related setting, Anderberg and Andersson (2003) show that education itself can have an insurance effect, if the government centrally decides on educational investment and that it should be overprovided in this case, because this increases both welfare and tax revenue.

Other recent papers, dealing with risky human capital formation and risky 
skilled labor income, are, e.g., García-Peñalosa and Wälde (2000), da Costa and Maestri (2007), Jacobs and van Wijnbergen (2007), Schindler and Yang (2007), and Anderberg (2008). Basically, all these contributions show that a graduate tax (respectively progressive income taxation), accompanied by some direct education subsidies, is optimal in order to insure individuals against income risks. Education subsidies then mitigate tax-induced distortions. The basic mechanism at work is thereby highly related to models of education and optimal redistribution among ex ante heterogenous individuals in deterministic worlds, see, among others, Bovenberg and Jacobs (2005), Jacobs and Bovenberg (2008), and Maldonado (2008).

Common to all these papers on wage risk is that they treat income risk as exogenous. There is no choice on learning effort, and therefore no effect of taxation on the probability distribution itself. This feature is illuminated in models focusing on the risk of failure (in education), which distinguish, therefore, two sectors: a skilled and an unskilled one.

Wigger and von Weizsäcker (2001) examine the case of ex ante and ex post moral hazard in such a setting and analyze different public policies. However, they restrict to two possible effort levels and the government cannot influence the learning technology by public educational spending. Andersson and Konrad (2003a,b) deal with endogenous learning effort in a risky setting as well and apply a two-period model, which is also the baseline of our approach. They focus on possible private insurance instead of governmental instruments (Andersson and Konrad, 2003a) as well as on hold-up problems and time-consistent taxation in case of a Leviathan government (Andersson and Konrad, 2003b). However, they do neither consider direct public spending in the educational sector nor endogenous labor supply in the working period. Accordingly, they are not able to deal with the issue of whether providing insurance against educational (failure) risk ex ante by enhancing the quality of education, i.e., by increasing the success probability, or ex post by granting income transfers.

This is done in Schindler and Weigert (2008), being mostly related to our modeling approach. They compare the First-best equilibrium to a Second-best optimum and show that, in the Second-best, quality of education becomes more 
important than income transfers. ${ }^{3}$ Therefore, the government applies both general and skill-specific tuition fees, as well as public real investment in the educational sector. Unskilled workers are net tax payers, but labor taxes are not used.

The present paper, now, significantly extends the scope: wage risk in an heterogenous skilled sector is introduced as technological change and the instruments of the government are increased by a graduate tax. This combines the two strands of the literature described above and tackles the questions, how to insure against multiple risk, what the optimal overall tax burden on skilled labor income should be, if any, and how the optimal combination of ex ante tuition fees and ex post fees, being proportional to income via graduate taxation, can be characterized.

\section{The Model}

We assume individuals of each generation living for two periods. In this overlapping generations model, each individual bears one child at the beginning of its second period of life and dies at the end of this period. Thus, there is no population growth. Moreover, we assume the mass of each cohort being normalized to one. During their life, individuals have to allocate one unit of time in each period. Assuming implicitly that individuals have already attended compulsory schooling, they spent their time on higher education by choosing their time effort $e \in[0,1]$ devoted to learning, and on leisure in their first period, $l_{1}=1-e$. In the second period, individuals start working and allocate time to their individual labor supply. As both education in the first period and working in the second period are time consuming activities, they generate disutility. Therefore, the fundamental structure of the model follows the tradition of Glomm and Ravikumar (1992).

However, individuals are exposed to two different kinds of risk: First, attending university does not guarantee an employment as skilled worker. Second, in case of skilled workers, their wage depends on an independently and idiosyncratically distributed stochastic factor $\theta$, which mirrors different productivities across

\footnotetext{
${ }^{3}$ Note that in Schindler and Weigert (2008) the term 'improving educational opportunities' is applied for increasing the success probability in education. We are now using 'enhancing the quality of education' in order to avoid any confusion with respect to the concept of 'equality of opportunities', which is not relevant for our topic and not related to our approach.
} 
industries in the skilled sector, being revealed only on the job and being driven by industry-specific technological shocks. These shocks affect the utilization and depreciation of human capital differently. ${ }^{4}$ Households might, therefore, differ in their innate abilities to cope with such technological shocks, however, this heterogeneity neither affects their success probability in the education process nor is the ability revealed before finding a job in the skilled sector. Thus, we can focus on a representative household.

The probability $p$ to pass the educational process successfully and to acquire a degree as skilled worker is determined by the effort invested into education $e$ and the endowment of the educational system $E$. This probability represents the quality of education, which the educational system provides. We assume the probability function $p(e, E)$ to be a concave function of learning effort, thus $e$ has a positive, but diminishing marginal productivity. This fits the stylized facts that higher education increases the probability of being employed, whilst unemployment is mostly concentrated among the unskilled (see, e.g., OECD (2007, Indicator A8)). Endowment $E$ is measured by public funding of the educational sector and is assumed to affect the quality of education positively, e.g., by increasing the number of professors and decreasing the ratio of students per teacher. Furthermore, private effort and public funding are assumed being complements, whereby an increase in public funding also increases the marginal productivity of each time unit invested. Thus, we have ${ }^{5}$

$$
p=p(e, E) \in[0,1)
$$

where $p(0, E)=0$, and $\frac{\partial p}{\partial e}=p_{e}>0, \frac{\partial p}{\partial E}=p_{E}>0, \frac{\partial^{2} p}{\partial e^{2}}, \frac{\partial^{2} p}{\partial E^{2}}<0, \frac{\partial^{2} p}{\partial e \partial E}=p_{e E}>$ 0 .

If an individual successfully graduates and enters the skilled sector, it will supply skilled labor instead of being employed as unskilled worker. Each graduate

\footnotetext{
${ }^{4}$ An alternative interpretation of the stochastic factor $\theta$ can be individual luck in final exams. This would follow the view that final grades are used by employers as indicator for real productivity of the graduate and therefore determine wage offers.

${ }^{5}$ This specification neglects private investment into the endowment of the educational system. This is a strong assumption. Incorporating this item would add much complexity to the analysis, but should not change the qualitative results as long as there is no perfect crowding out in private and public resource investment.
} 
is supplied with one unit of human capital, but its effective labor supply depends on a stochastic factor $\theta$ as well. $\theta \in\left[w_{L} / w_{H}, \infty\right)$ gives rise for idiosyncratic wage risk, then. This mirrors the fact that human capital can be utilized differently, dependent on the kind of job. This corresponds to individual uncertainty about productivity in different jobs, to differences in the ability to cope with industryspecific technological change and to the luck to get well-paid job openings. ${ }^{6}$

For sake of simplification, we assume that the stock of human capital is independent of learning effort $e$. In principle, a human capital production function $F^{H}$ should also depend on effort and endowment, consequently $F^{H}=F^{H}(e, E, \theta)$ with $F_{j}^{H}>0, F_{j j}^{H}<0, j=e, E$. Admittedly, the reduced version $F^{H}(\theta)=\theta$ is sufficient in order to concentrate on the issues of educational and wage risk, because endogenous labor supply will capture most of the neglected effects and most of the results presented later would not change qualitatively by using a more sophisticated human capital production - but the analysis itself would become much more complicated.

Wage risk realizes at the beginning of the second period, and all graduates start working as skilled workers afterwards, supplying $\theta_{i} \cdot H_{i}$ units of effective labor in industry $i$. Those who fail to enter the skilled labor market are not faced by any wage risk and supply $L$ units of labor as unskilled workers. In the second period individuals are endowed with one divisible unit of time, accordingly time $1-H_{i}$, respectively $1-L$, is consumed as second-period leisure. Total wage income is spent on total family consumption.

It is important to distinguish between educational and wage risk, because they significantly differ in the ways to insure against. The former kind of risk implies that households choose their probability for entering the skilled sector optimally, and consequently, the probability distribution is endogenized. Then, the government can provide ex ante insurance by increasing the success probability via public investment. This can be seen as enhancing the quality of education, i.e., improving the efficiency of the education system as a filter technology and allowing more students to pass on into the skilled sector, see Konrad (2004). Note

\footnotetext{
${ }^{6}$ Again, an another explanation can be that salaries depend to some extent on grades in final exams. Thus, salaries depend also on individual fate (or the individual risk of a bad hair day) in these exams.
} 
that this is important even if the playing field is leveled or if the individuals are homogenous ex ante, e.g., with respect to ability. Contrary to standard models, relying on wage risk and decentralized decision making with respect to educational investment, governmental spending in the education sector or subsidization of education has accordingly a direct insurance effect here.

The latter kind of risk also allows to adjust the exposure to risk by educational investment by households and income redistribution by the government. However, the distribution of entry probabilities for the possible states of nature is exogenously given, educational policy does not provide any insurance effect and ex post insurance (e.g., by taxation) is the only social insurance device. The present model enables us to analyze both the interplay of these risks and the optimal social insurance mix.

Social insurance is desirable, because it will be assumed throughout the paper that private insurance is not available - neither against educational risk nor against wage risk. This might be because of market failure due to adverse selection and moral hazard and the fact that human capital cannot serve as collateral, see, e.g., Eaton and Rosen (1980b), or the fact that individuals are too young to write insurance contracts, when they decide on their human capital investment (Sinn, 1996). ${ }^{7}$

All individuals have identical preferences which are defined over leisure in period one and two, $l_{1}$ and $l_{2}$, and over total family consumption $C$ in period two. Formally, the preferences are described by a von Neumann-Morgenstern expected utility function which is additively separable in its intertemporal components. Thus, we have

$$
\mathrm{E}[U]=U_{1}(1-e)+p(e, E) \cdot \mathrm{E}\left[U_{2}\left(C_{H_{i}}, 1-H_{i}\right)\right]+[1-p(e, E)] \cdot U_{2}\left(C_{L}, 1-L\right),
$$

where $H_{i}=1-l_{2 H i}$ denotes second period labor supplied by a skilled worker of type $i$, whose human capital realized as $\theta_{i}$. Accordingly, $L=1-l_{2 L}$ denotes labor supplied by an unskilled worker in the second period. ${ }^{8}$ In order to ensure an interior solution, especially for learning effort $e=1-l_{1}$, we assume that the

\footnotetext{
${ }^{7}$ These arguments are in the major line of the literature. An opposing view and some discussion of this assumption is to be found in Andersson and Konrad (2003a).

${ }^{8}$ Subscripts $H$ and $L$ denote the respective values for the different skill groups, subscript $i$ indicates the realization of wage risk $\theta$ for a skilled worker.
} 
utility function meets the following Inada conditions:

Assumption 1. First and second period utility exhibits the following properties:

$$
\begin{array}{rl}
\frac{\partial U_{j}}{\partial l_{j}}, \frac{\partial U_{2}}{\partial C}>0, \frac{\partial^{2} U_{j}}{\partial l_{j}^{2}}, \frac{\partial^{2} U_{2}}{\partial C^{2}}<0 & j=1,2 \\
\lim _{l_{j} \rightarrow 0} \frac{\partial U_{j}}{\partial l_{j}}=\lim _{C \rightarrow 0} \frac{\partial U_{2}}{\partial C} \rightarrow \infty, \lim _{l_{j} \rightarrow 1} \frac{\partial U_{j}}{\partial l_{j}}=\lim _{C \rightarrow \infty} \frac{\partial U_{2}}{\partial C}=0 & j=1,2 .
\end{array}
$$

(Nominal) Wages for both skill groups are exogenously given and denoted by $w_{H}$ and $w_{L}$ respectively. This fits to assuming a small open economy. The government can apply a broad set of policy instruments: First, there is a linear income tax scheme consisting of a constant tax rate $t$ and a lump-sum transfer $T$. The lump-sum transfer can turn negative and will be interpreted as general tuition fee, if $T<0$. Second, skilled workers are liable to a proportional surtax, where their income is additionally taxed at rate $t^{H}$. This fulfills the definition of a graduate tax (see. e.g., Jacobs (2002, Section 2)), where repayments are proportional to earned income, but independent of the initial subsidy/loan received and where they can exceed this amount substantially (or remain less, accordingly providing even better insurance). ${ }^{9}$ Third, successfully entering the skilled sector is subject to skill-specific tuition fees $f_{B}$. These fees can be motivated as follows: Assume that the government collects tuition fees from each student entering university, but at the same time pre-finances these fees by granting a compulsory public credit $f_{B}$. This credit has to be repaid after successful graduation and entering the skilled sector. Consequently, there are no real payments in the first period of life and the repayment in the second period is settled in terms of a skill-contingent loan. Only households, which successfully entered the skilled sector have to pay the fixed amount $f_{B}$. Note that we do not require the tuition fees to cover all public expenses for higher education. Instead, the government can use a mix of instruments to finance higher education.

Put together, we apply de facto a full set of skill specific taxes. Combining the tax instruments described above, and assuming concomitant adjustment

\footnotetext{
${ }^{9}$ In fact, a graduate tax can be seen as an equity stake of the government in human capital of graduates. See Jacobs and van Wijnbergen (2007).
} 
where necessary, there is a skill-specific wage tax on unskilled labor supply at rate $t^{U}=t$, whereas labor income of skilled workers is liable to a skill-specific wage tax at rate $t^{S}=t+t^{H}$. Moreover, there are two skill-specific per-capita transfers or poll taxes: unskilled workers receive a transfer $T^{U}=T$, whereas skilled workers are faced by skill-specific net payments of $T^{S}=f_{B}-T$. For these taxes to be implemented, the government does not need to know individual wages or hours worked, but observes total wage income and it knows whether a worker is employed in the skilled or the unskilled sector. The latter is a strong assumption, as this informational requirement is necessary to avoid moral hazard behavior. There might be a strong incentive to mimic an unskilled worker, if the skill status were private information. Note that this set of instruments does not allow to implement a First-best solution, because learning effort cannot be controlled. Dealing with the resulting moral hazard problem in educational investment will be one of the main tasks of this paper.

The budget constraint of a skilled household $i$ can then be written as

$$
C_{H i}=\left(1-t-t^{H}\right) \cdot w_{H} \cdot \theta_{i} \cdot H_{i}-f_{B}+T,
$$

whereas consumption of an unskilled household is given by

$$
C_{L}=(1-t) \cdot w_{L} \cdot L+T
$$

Both kinds of risk being present in the economy are idiosyncratic. Accordingly, there are ex post $p(e, E)$ skilled workers and $1-p(e, E)$ unskilled ones in each generation. Total labor supply of the skilled workers is given by $p(e, E) \cdot \mathrm{E}\left[\theta_{i}\right.$. $\left.H_{i}\right]$. The government uses its instruments in order to maximize the utility of a representative steady-state generation. The government thereby faces a trade-off between efficient financing of public expenditure and optimal insurance against the risks of education. The latter implies on the one hand redistribution between successful and unsuccessful students and on the other hand redistribution between lucky and unlucky skilled workers.

In a nutshell, the timing structure and the model can be summarized as follows: First, the benevolent government decides on public funding of the educational 
sector and on the tax instruments. ${ }^{10}$ Second, the young generation will choose learning effort given wages, the probability distribution of $\theta$ and the governmental decisions. This in turn determines the success probability $p(e, E)$, and with it the fraction of skilled and unskilled workers. At the beginning of the second period wage risk $\theta$ realizes and each individual knows both whether it graduated or failed and which effective wage it will earn. Based on this knowledge, it then decides on its labor supply. In the following, we will solve the model by backward induction.

\section{Household Behavior}

The decision problem of a representative household is given by:

$$
\begin{aligned}
\max _{\left\{e, H_{i}, C_{H i}, L, C_{L}\right\}} \mathrm{E}[U] & =U_{1}(1-e)+p(e, E) \cdot \mathrm{E}\left[U_{2}\left(C_{H i}, 1-H_{i}\right)\right] \\
& +[1-p(e, E)] \cdot U_{2}\left(C_{L}, 1-L\right) \text { s.t. (3) and (4) }
\end{aligned}
$$

Substituting (3) and (4) into (5) then yields the following first order conditions:

$$
\begin{aligned}
& \frac{\partial \mathrm{E}[U]}{\partial H_{i}}=U_{2 C}\left(C_{H i}, 1-H_{i}\right) \cdot\left(1-t-t^{H}\right) w_{H} \theta_{i}-U_{2 l_{2}}\left(C_{H i}, 1-H_{i}\right)=0(6) \\
& \frac{\partial \mathrm{E}[U]}{\partial L}=U_{2 C}\left(C_{L}, 1-L\right) \cdot(1-t) w_{L}-U_{2 l_{2}}\left(C_{L}, 1-L\right)=0 \\
& \frac{\partial \mathrm{E}[U]}{\partial e}=-U_{1 l_{1}}(1-e)+p_{e}\left\{\mathrm{E}\left[U_{2}\left(C_{H i}, 1-H_{i}\right)\right]-U_{2}\left(C_{L}, 1-L\right)\right\}=0 .(8)
\end{aligned}
$$

These first order conditions (6)-(8) imply a block recursive system: optimal labor supply $H_{i}^{*}, L^{*}$ and with it optimal consumption $C_{H i}^{*}, C_{L}^{*}$ are separately defined by (6) and (7) respective. ${ }^{11}$ Optimal consumption and labor supply of both skill groups depend on the labor tax rate $t$, on the lump-sum transfer $T$ and on the respective wage rate $w_{H}, w_{L}$. Additionally, both the graduate tax rate $t^{H}$ and skill-specific tuition fees $f_{B}$ are only relevant for labor supply and consumption

\footnotetext{
${ }^{10} \mathrm{We}$ thereby assume that the government can credibly commit to its chosen tax instruments, and we do not consider any hold-up and time-consistency problem. Moreover, we do not focus on extortionary Leviathan governments. See Andersson and Konrad (2003b) for these issues in a related context.

${ }^{11}$ Throughout the paper, asterisks denote optimal values. To simplify the notation, we drop the functional arguments $t, T, t^{H}, f_{B}, w_{H}, w_{L}$ when this causes no confusion.
} 
of skilled workers. Inserting optimal labor supply and consumption into the second period utility function leads to the indirect (expected) utility function for both types of workers: $V^{H}=\mathrm{E}\left[U_{2}\left(C_{H i}^{*}, 1-H_{i}{ }^{*}\right)\right], V^{L}=U_{2}\left(C_{L}^{*}, 1-L^{*}\right)$. Optimal learning effort $e^{*}=e\left(t, T, t^{H}, f_{B}, E, w_{H}, w_{L}\right)$ is obtained by applying the respective indirect utility functions $V^{H}$ and $V^{L}$ in (8). Evaluating first period utility at the optimal effort $e^{*}$ delivers the first period indirect utility function $V=U\left(1-e^{*}\right)$.

Given the properties of the utility functions stated in assumption 1 and the block recursive form of the first order conditions, it is sufficient to check the second order conditions of (5) for each separate variable:

$$
\begin{aligned}
\left.\frac{\partial^{2} \mathrm{E}[U]}{\partial H_{i}^{2}}\right|_{H_{i}=H_{i}^{*}} & =S O C\left(H_{i}\right) \\
& =U_{2 C C}(1-t)^{2} w_{H}^{2} \theta_{i}^{2}-2 U_{2 C l_{2}}\left(1-t-t^{H}\right) w_{H} \theta_{i}+U_{2 l_{2} l_{2}}<0 \\
\left.\frac{\partial^{2} \mathrm{E}[U]}{\partial L^{2}}\right|_{L=L^{*}} & =S O C(L) \\
& =U_{2 C C}(1-t)^{2} w_{L}^{2}-2 U_{2 C l_{2}}(1-t) w_{L}+U_{2 l_{2} l_{2}}<0 \\
\left.\frac{\partial^{2} \mathrm{E}[U]}{\partial e^{2}}\right|_{e=e^{*}} & =S O C(e) \\
& =U_{1 l_{1} l_{1}}+p_{e e}\left(V^{H}-V^{L}\right)<0 .
\end{aligned}
$$

The inequality in equation (11) is given by decreasing marginal utility of leisure, and decreasing marginal productivity of learning, and by the fact that a skilled worker must have higher utility in the second period than an unskilled one, $V^{H}>V^{L}$, because else there will be no learning effort at all.

In the next sections we derive the optimal policy mix. For that reason, we need to derive some comparative statics of the individual choice variables with respect to the different instruments. We start by calculating the comparative statics of 
labor supply by skilled workers:

$$
\begin{aligned}
\frac{\partial H_{i}^{*}}{\partial t} & =-\frac{-U_{2 C C}\left(1-t-t^{H}\right) w_{H}^{2} \theta_{i}^{2}+\left(U_{2 C l_{2}}-U_{2 C}\right) \cdot w_{H} \theta_{i}}{S O C\left(H_{i}\right)} \\
& =\frac{\partial H_{i}^{*}}{\partial t^{H}} \lessgtr 0 \\
\frac{\partial H_{i}^{*}}{\partial T} & =-\frac{\partial H_{i}^{*}}{\partial f_{B}}=-\frac{U_{2 C C}\left(1-t-t^{H}\right) w_{H} \theta_{i}-U_{2 C l_{2}}}{S O C\left(H_{i}\right)}<0,
\end{aligned}
$$

where we have assumed that leisure is a normal good. Hereby, it is less important to disentangle income and substitution effects, but to show that (i) the effects of a general wage tax and a graduate tax on skilled labor supply and (ii) the (income) effects of the lump-sum transfer and skill-specific tuition fees are identical.

By the very same analysis we obtain comparative static results for learning effort $e^{*}$ with respect to the lump-sum transfer $T$ :

$$
\frac{\partial e^{*}}{\partial T}=-\frac{p_{e} \cdot\left(\mathrm{E}\left[\alpha^{H i}\right]-\alpha^{L}\right)}{S O C(e)}<0
$$

with $\alpha^{j}=\frac{\partial V^{j}}{\partial C}>0, j=H, L$ denoting the marginal utility of income. Assuming agent monotonicity and the single crossing property (Mirrlees, 1976) to hold, equation (14) always holds as strict inequality. These assumptions imply that a skilled household always commands a higher (expected) income than an unskilled worker, and hence $\mathrm{E}\left[\alpha^{H i}\right]<\alpha^{L}$. The intuition is straightforward: any increase in lump-sum income $T$ decreases the learning intensity $e$, because an educational degree gets marginally less attractive.

An increase in skill-specific tuition fees changes learning effort according to

$$
\frac{\partial e^{*}}{\partial f_{B}}=\frac{p_{e} \cdot \mathrm{E}\left[\alpha^{H i}\right]}{S O C(e)}<0
$$

while increased public spending in education $E$ changes the effort according to

$$
\frac{\partial e^{*}}{\partial E}=-\frac{p_{e E} \cdot\left(V^{H}-V^{L}\right)}{S O C(e)}>0 .
$$


Learning effort is unambiguously reduced if skill-specific tuition fees rise because this directly reduces the returns to education and creates a negative substitution effect, whilst increased spending in education increases the productivity of learning, and therefore learning effort.

A rise in graduate taxation will unambiguously reduce learning effort as well. The intuition is analogous to the case of skill-specific tuition fees: a rise will decrease the return to educational investment. This can be seen by

$$
\frac{\partial e^{*}}{\partial t^{H}}=\frac{p_{e} \mathrm{E}\left[\alpha^{H i} \cdot w_{H} \theta_{i} H_{i}^{*}\right]}{S O C(e)}<0 .
$$

Contrary to these effects, the effect of an increase in the wage tax $t$ is less clear. Increasing ceteris paribus the tax burden on skilled wage income decreases learning effort, because the returns to schooling decrease. Increasing ceteris paribus the wage tax for unskilled worker increases the returns to schooling and increases the learning intensity. Combining both effects, we end up with

$$
\frac{\partial e^{*}}{\partial t}=-\frac{p_{e}\left(\alpha^{L} \cdot w_{L} L^{*}-\mathrm{E}\left[\alpha^{H i} \cdot w_{H} \theta_{i} H_{i}^{*}\right]\right)}{S O C(e)} \lessgtr 0 .
$$

Applying optimal household behavior in equation (5), we obtain the indirect expected utility function of a household as

$$
\begin{aligned}
\mathrm{E}\left[V^{*}\left(t, T, t^{H}, f_{B}, E\right)\right] & =V\left(t, T, t^{H} f_{B}, E\right) \\
& +p\left(e^{*}, E\right) \cdot V^{H}\left(t, T, t^{H}, f_{B}\right)+\left[1-p\left(e^{*}, E\right)\right] \cdot V^{L}(t, T) .
\end{aligned}
$$

By using the envelope-theorem we can derive the marginal impact of a policy change on the expected utility of a household, which will be helpful in deriving 
optimal government action in the next sections:

$$
\begin{aligned}
& \frac{\partial \mathrm{E}\left[V^{*}\right]}{\partial f_{B}}=-p^{*} \cdot \mathrm{E}\left[\alpha^{H i}\right]<0, \\
& \frac{\partial \mathrm{E}\left[V^{*}\right]}{\partial T}=p^{*} \cdot \mathrm{E}\left[\alpha^{H i}\right]+\left(1-p^{*}\right) \cdot \alpha^{L}>0, \\
& \frac{\partial \mathrm{E}\left[V^{*}\right]}{\partial t^{H}}=-p^{*} \cdot \mathrm{E}\left[\alpha^{H i} \cdot w_{H} \theta_{i} H_{i}^{*}\right]<0, \\
& \frac{\partial \mathrm{E}\left[V^{*}\right]}{\partial t}=-p^{*} \cdot \mathrm{E}\left[\alpha^{H i} \cdot w_{H} \theta_{i} H_{i}^{*}\right]-\left(1-p^{*}\right) \cdot \alpha^{L} \cdot w_{L} L^{*}<0, \\
& \frac{\partial \mathrm{E}\left[V^{*}\right]}{\partial E}=p_{E}^{*} \cdot\left[V^{H}-V^{L}\right]>0 .
\end{aligned}
$$

\section{Public Policy}

As both educational and wage risk are idiosyncratic, there is no risk in aggregate. The government is faced by deterministic values due to the law of large numbers. Hence, from a policy maker's perspective, there are $\left[1-p\left(e^{*}, E\right)\right]$ unskilled workers supplying $\left(1-p^{*}\right) \cdot L^{*}$ efficiency units of unskilled labor. Furthermore, $p\left(e^{*}, E\right)$ skilled workers supply $p^{*} \cdot \mathrm{E}\left[\theta_{i} \cdot H_{i}^{*}\right]$ efficiency units of skilled labor.

Assuming a benevolent government, the aim is to maximize social welfare. For this purpose, resources can be spent on education, determining the quality of the education system, and a lump-sum transfer $T$ can be granted to all households. Moreover, welfare is determined by taxes and tuition fees, which are necessary in order to finance overall expenditure $E+T$. Tax revenue is created by implementing a proportional wage tax at rate $t$ on all labor incomes, by usage of a graduate tax at rate $t^{H}$ on skilled labor income and by skill-specific tuition fees $f_{B}$.

Thus, the governmental budget constraint can be written as

$$
E+T=p^{*} \cdot\left\{\left(t+t^{H}\right) w_{H} \mathrm{E}\left[\theta_{i} \cdot H_{i}\right]+f_{B}\right\}+\left(1-p^{*}\right) \cdot t w_{L} L .
$$

Formally, the maximization problem for social welfare $\mathrm{E}\left[V^{*}\left(E, f_{B}, t, T, t^{H}\right)\right]$ can 
then be written as: ${ }^{12}$

$$
\max _{\left\{E, f_{B}, t, T, t^{H}\right\}} \mathrm{E}\left[V^{*}\left(E, f_{B}, t, T, t^{H}\right)\right] \quad \text { s.t. } \quad(25) .
$$

Using $E$, the government can directly influence the percentage of skilled and unskilled workers. Skill-specific tuition fees $f_{B}$ provide both insurance and efficient redistribution between these groups and affect indirectly the shares of skilled and unskilled workers via incentives for learning effort. The wage tax $t$ has analogous effects, but distorts labor supply. However, the wage tax has only a moderate effect on learning effort and additionally redistributes income between skilled households. Therefore, it provides an extended insurance effect. The graduate tax $t^{H}$ has a similar impact: income fluctuations in between skilled households are reduced and the gap between skilled and unskilled labor income is narrowed - but labor supply distortions are created only in the skilled sector (whereas it causes more distortions in learning effort than a general wage tax).

Schindler and Weigert (2008) show in a similar setting, but without wage risk in the skilled sector, that a wage tax is optimally not used. Skill-specific tuition fees provide insurance and redistribution between skilled and unskilled workers at lower costs, if they are combined with enhancing the quality of education. In the present model, however, heterogeneity of skilled households calls also for redistribution within the group of skilled. This should give support for labor taxation at least via graduate taxation of the skilled.

Thus, the questions emerging are now: (i) What is the optimal overall tax burden on skilled labor income, if any? (ii) Is it - following Lipsey-Lancaster intuition - optimal to tax and to distort unskilled labor supply as well? (iii) What is the optimal combination of ex ante tuition fees, enhancing educational quality and of ex post fees via graduate taxation, the latter being proportional to income? (iv) What are the effects on public investment in education?

\footnotetext{
${ }^{12}$ Note that we are going to assume $V^{H}>V^{L}$ to hold in order to ensure $e^{*}>0$. Thus, we focus on interior solutions. There might be a corner solution else, restricting both governmental instruments and maximum net taxes on skilled workers. Note as well that in any case a selfselection constraint is not necessary due to the information set of the government.
} 


\section{Optimal Taxation in Case of Educational and Wage Risk}

Solving the first stage of the game and anticipating optimal household behavior on the second stage, the Lagrangian $\mathcal{L}$ to equation (26) delivers the following first order conditions:

$$
\begin{aligned}
\frac{\partial \mathcal{L}}{\partial f_{B}} & =-p^{*} \bar{\alpha}^{H}+\lambda\left(p^{*}+p^{*} A \cdot \mathrm{E}\left[\frac{\partial\left(\theta_{i} \cdot H_{i}^{*}\right)}{\partial f_{B}}\right]+B p_{e}^{*} \frac{\partial e^{*}}{\partial f_{B}}\right)=0 \\
\frac{\partial \mathcal{L}}{\partial T} & =p^{*} \bar{\alpha}^{H}+\left(1-p^{*}\right) \alpha^{L}+\lambda\left(-1+p^{*} A \cdot \mathrm{E}\left[\frac{\partial\left(\theta_{i} \cdot H_{i}^{*}\right)}{\partial T}\right]\right) \\
& +\lambda\left(\left(1-p^{*}\right) t w_{L} \frac{\partial L^{*}}{\partial T}+B p_{e}^{*} \frac{\partial e^{*}}{\partial T}\right)=0 \\
\frac{\partial \mathcal{L}}{\partial t} & =-p^{*} \mathrm{E}\left[\alpha^{H} w_{H} \theta_{i} H_{i}^{*}\right]-\left(1-p^{*}\right) \alpha^{L} w_{L} L^{*} \\
& +\lambda\left(p^{*} A \cdot \mathrm{E}\left[\frac{\partial\left(\theta_{i} \cdot H_{i}^{*}\right)}{\partial t}\right]+\left(1-p^{*}\right) t w_{L} \frac{\partial L^{*}}{\partial t}+B p_{e}^{*} \frac{\partial e^{*}}{\partial t}\right) \\
& +\lambda\left(p^{*} w_{H} \mathrm{E}\left[\theta_{i} \cdot H_{i}^{*}\right]+\left[1-p^{*}\right] w_{L} L^{*}\right)=0, \\
\frac{\partial \mathcal{L}}{\partial t^{H}} & =-p^{*} \mathrm{E}\left[\alpha^{H} w_{H} \theta_{i} H_{i}^{*}\right]+\lambda p^{*} w_{H} \mathrm{E}\left[\theta_{i} \cdot H_{i}^{*}\right] \\
& +\lambda\left(p^{*} A \cdot \mathrm{E}\left[\frac{\partial\left(\theta_{i} \cdot H_{i}^{*}\right)}{\partial t^{H}}\right]+B p_{e}^{*} \frac{\partial e^{*}}{\partial t^{H}}\right)=0 \\
\frac{\partial \mathcal{L}}{\partial E} & =p_{E}^{*}\left[V^{H}-V^{L}\right]+\lambda\left(-1+B\left[p_{e}^{*} \frac{\partial e^{*}}{\partial E}+p_{E}^{*}\right]\right)=0
\end{aligned}
$$

where $\lambda$ represents the Lagrangian multiplier, where we have applied the Envelope effects (20)-(24), where $\bar{\alpha}^{H}=\mathrm{E}\left[\alpha^{H_{i}}\right]$, where $A=\left(t+t^{H}\right) \cdot w_{H}$ is the tax wedge on skilled labor supply and where $B=\left(t+t^{H}\right) \cdot w_{H} \mathrm{E}\left[\theta_{i} \cdot H_{i}^{*}\right]+f_{B}-t \cdot w_{L} \cdot L^{*}$ represents the average net tax wedge on learning effort.

Relying on optimal household's behavior and comparative statics, some first order conditions of the governmental optimization problem can be rearranged to result in equations (32) and (33): ${ }^{13}$

$$
\frac{t+t^{H}}{1-t-t^{H}}=\left[\frac{\bar{\alpha}^{H}}{V^{H}-V^{L}} \cdot \frac{h(p) \cdot B}{A R A(e)+h\left(p_{e}\right)}+\frac{\bar{\alpha}^{H}}{\lambda}\right] \cdot \frac{\xi(\theta)}{\epsilon_{H H}},
$$

\footnotetext{
${ }^{13}$ See the Appendix for an explicit derivation of these expressions.
} 
where $h\left(p_{e}\right)=-\frac{p_{e e}}{p_{e}}>0$ as hazard rate determines, how fast marginal productivity of learning effort decreases, where $h(p)=\frac{p_{e}^{*}}{p^{*}}>0$ is the hazard rate (or partial growth rate) of the success probability function and where $A R A(e)=-\frac{U_{1 l_{1} l_{1}}}{U_{l_{1}}}>0$ equals absolute risk aversion in first period leisure respectively learning effort. $\epsilon_{H H}=\frac{\left(1-t-t^{H}\right) w_{H}}{\mathrm{E}\left[\theta_{i} \cdot H_{i}^{*}\right]} \cdot \mathrm{E}\left[S_{H H}\right]>0$ represents the (expected) compensated (net) wage elasticity of effective skilled labor supply and $\xi(\theta)=-\frac{\operatorname{Cov}\left(\alpha^{H}, w_{H} \cdot \theta_{i} \cdot H_{i}^{*}\right)}{\bar{\alpha}^{H} \cdot w_{H} \cdot \operatorname{E}\left[\theta_{i} \cdot H_{i}^{*}\right]}>0$ is the insurance characteristic, being defined analogously to Feldstein's distributional characteristic (see Feldstein, 1972). Therefore, $\xi(\theta)$ measures the concern of the government for providing insurance against skilled wage risk.

$$
\frac{t}{1-t} \cdot\left(1-p^{*}\right) \cdot w_{L} L^{*} \cdot \epsilon_{L L}=0
$$

where $\epsilon_{L L}$ is the compensated (net) wage elasticity of unskilled labor supply.

Referring to equations (32) and (33), we can now infer the following conclusions:

Proposition 1. Even if there is wage uncertainty for skilled workers and positive labor taxation in the skilled sector, there will be no general labor taxation and unskilled leisure choice remains undistorted, as long as the government has access to skill-specific tuition fees $f_{B}$ and unconstrained lump-sum transfers (uniform tuition fees) $T$. Hence, $t=0$.

Proof. Unconstrained lump-sum transfer implies that this transfer can turn into a uniform tuition fee (lump-sum tax) $T<0$, which has to be paid irrespectively of being successful or not in educational investment. Applying then (33) and recognizing the compensated elasticity $\epsilon_{L L}$ as well as the wage bill of unskilled workers to be positive, it must be $t=0$.

A general wage tax is neither used to insure against any risk nor to provide redistribution between households. Labor choice in the unskilled sector remains undistorted, as there is no need for redistribution between unskilled workers.

With respect to the skilled sector, introducing wage and income risk for skilled workers reanimates, however, the traditional income insurance via labor taxation à la Eaton and Rosen $(1980 \mathrm{a}, \mathrm{b})$ - but it is restricted to graduate taxation, which is 
only faced by the skilled. To show this, we make use of the following lemma:

Lemma 1. There is always a positive average net tax burden on education $B=$ $\left(t+t^{H}\right) \cdot w_{H} E\left[\theta_{i} \cdot H_{i}^{*}\right]+f_{B}-t \cdot w_{L} \cdot L^{*}>0$. This also guarantees $\alpha^{L}>\lambda$.

Proof. See Appendix.

Then, we conclude from equation (32):

Proposition 2. In case of educational risk and wage risk in the skilled sector, it is optimal to implement a positive graduate taxation $t^{H}>0$, which balances insurance by reducing wage fluctuations and efficiency losses caused by distorting skilled labor supply.

Proof. The insurance characteristic is positive by definition, and so is the compensated wage elasticity $\epsilon_{H H}$. The ratio between the insurance characteristic and the wage elasticity in the second factor of the RHS in equation (32) mirrors the trade-off between the insurance effect and distortions in labor supply.

In order to guarantee positive graduate taxation, the squared bracket on the RHS of equation (32) must also be positive. Herein, the hazard rates $h(p), h\left(p_{e}\right)$ and absolute risk aversion $A R A(e)$ are defined as positive values as are marginal utility of (skilled) income, $\bar{\alpha}^{H}$, respectively marginal costs of tax revenue, $\lambda$. Moreover, $V^{H}>V^{L}$ from household choice, ensuring $e^{*}>0$, and we have $B>0$ from Lemma 1. Consequently, the squared bracket is positive, and accordingly $t^{H}>0$.

Positive graduate taxation achieves two aims: ${ }^{14}$ ex ante it reduces wage risk for skilled workers, and ex post it narrows the income gap between the skilled and the unskilled households, thus it implicitly provides redistribution. Distortions in labor supply are balanced with reduced uncertainty and a welfare enhancing insurance effect. Accordingly, this partial result is in line with standard models featuring income risks and taxation (e.g., Eaton and Rosen (1980b), Hamilton (1987), but also Anderberg and Andersson (2003)). If there is, instead, no wage risk, the insurance characteristic $\xi(\theta)$ vanishes, and there is no need for distorting

\footnotetext{
${ }^{14}$ Negative graduate taxation would economically be senseless, anyway. Wage subsidies increase income risk and cause efficiency losses via distortions, which cannot be optimal.
} 
taxation at all - consequently $t^{H}=0$ and we are back in the model and the results in Schindler and Weigert (2008).

Efficiency losses due to distortions, measured as overall marginal costs of tax revenue relative to pure income effects $\lambda>\bar{\alpha}^{H}$, have a dampening effect on graduate taxation. Moreover, success in education plays a role in determining the optimal wage tax rate. From equation (32) can be inferred: the more sensitive marginal productivity of learning effort $h\left(p_{e}\right)$ is, the lower should the optimal tax rate be, whereas a higher growth rate of the success probability $h(p)$ allows for higher taxation. Last but not least, attitudes towards risk in learning investment, $A R A(e)$, have a major impact.

The optimal tax rate $t^{H}$ in (32) decreases in absolute risk aversion in educational investment. This can be best rationalized under the standard assumption of decreasing absolute risk aversion: The negative income effect of wage taxation increases risk aversion $A R A(e)$. Higher risk aversion then decreases learning effort and, therefore, the success probability, i.e., quality of education. Accordingly,

Corollary 1. Assuming decreasing absolute risk aversion, high absolute risk aversion in learning effort decreases ceteris paribus optimal graduate taxation, in order to avoid negative (income) effects on the quality of education.

Proof. In case of decreasing absolute risk aversion, a wealth reduction by taxation increases risk aversion and decreases risky investment, here learning effort. Hence, the negative relationship between $A R A(e)$ and $t^{H}$ in equation (32) can be interpreted as avoiding excessively negative risk effects of graduate taxation on learning effort and the success probability.

In case of educational (failure) risk in graduating and wage risk within the industries of the skilled sector, all distortions in labor supply are concentrated among the skilled workers. This is amazing, because the result by Lipsey and Lancaster (1956), stating the introduction of several distortions to be worth while as long as the First-best cannot be reached, does still not apply. Intuitively, one would expect the wage tax to be positive, $t>0$, because it has the same effects like graduate taxation with respect to wage risk, similar effects with respect to educational risk and weighes induced distortions in unskilled labor supply against 
only moderate distortions in learning effort. Looking at the optimal tax structure, however, it is still not optimal to introduce distortions in the unskilled sector, although we have strong distortions in learning effort and in labor supplied in the skilled sector, and though production efficiency cannot be guaranteed. The reason for this result is that distortions in learning effort can be mitigated by enhancing the quality of education, as will be shown later. The labor tax is then dominated by combinations of the other instruments.

Put together, Propositions 1 and 2 imply:

Corollary 2. Although there are distortions in learning effort and skilled labor supply, the Lipsey-Lancaster-theorem cannot be applied, because it is still not optimal to distort unskilled labor supply, as $t=0$. Thus, insuring the skilled against wage risk can be seen as dichotomic task.

Turning to skill-specific tuition fees, it is, unfortunately, not possible to determine the sign of $f_{B}$ in general. To show this, let us define the expected (or from the ex post view: the average) net social marginal value of income, including income effects on the tax base, as

$$
\bar{b}=p^{*} \cdot \frac{\bar{\alpha}^{H}}{\lambda}+\left(1-p^{*}\right) \cdot \frac{\alpha^{L}}{\lambda}+p^{*} \cdot t^{H} \cdot w_{H} \cdot \mathrm{E}\left[\frac{\partial\left(\theta_{i} \cdot H_{i}\right)}{\partial T}\right]+B \cdot p_{e} \cdot \frac{\partial e}{\partial T},
$$

where we have already used $t=0$. Accordingly, the net social marginal valuation of income of an unskilled household is given by

$$
b^{L}=\frac{\alpha^{L}}{\lambda}+B \cdot p_{e} \cdot \frac{\partial e}{\partial T} .
$$

Note that the only effect on the tax base is due to a change in the likelihood to get skilled and to have to pay taxes on education, then.

It is straightforward from rearranging FOC (28) that the standard condition

$$
\bar{b}=1
$$

has to hold true.

Next, let us define $\epsilon_{e f_{B}}=\frac{\frac{\partial e}{\partial f_{B}}+p^{*} \cdot \frac{\partial e}{\partial T}}{e}<0$ as the compensated elasticity of 
learning effort with respect to skill-specific tuition fees. Reverting to equation (50) in the proof to Lemma 1, we find the optimal average tax burden on learning effort to be

$$
B=\frac{1-p^{*}}{p^{*}} \cdot \frac{b^{L}-\bar{b}}{\epsilon_{p e} \cdot\left(-\epsilon_{e f_{B}}\right)}>0,
$$

where $b^{L}-\bar{b}>0$ and where $\epsilon_{p e}=\frac{e}{p^{*}(e, E)} \cdot p_{e}^{*}>0$ is the elasticity of the success probability with respect to a change in learning effort.

Thus, optimal tax payments of the skilled for being successful in getting an employment in the skilled sector weigh gains from redistribution ${ }^{15}$ against induced distortions by skill-specific fees in learning effort $\left(\epsilon_{e f_{B}}\right)$ and how these translate into a decrease in quality of education $\left(\epsilon_{p e}\right)$. The higher the gap between income valuation by the unskilled to the average valuation in society, the higher net taxes on successful education will be. The more elastic learning effort and the more sensitive the success probability are, the more excess burden will be created and the less net taxes on successful education will be raised.

Relying on $B=t^{H} \cdot w_{H} \cdot \mathrm{E}\left[\theta_{i} \cdot H_{i}^{*}\right]+f_{B}$, the optimal skill-specific tuition fees turn out to be

$$
f_{B}=\frac{1-p^{*}}{p^{*}} \cdot \frac{b^{L}-\bar{b}}{\epsilon_{p e} \cdot\left(-\epsilon_{e f_{B}}\right)}-t^{H} \cdot w_{H} \cdot \mathrm{E}\left[\theta_{i} \cdot H_{i}^{*}\right] .
$$

Skill-specific tuition fees, $f_{B}>0$, can be optimal as in Schindler and Weigert (2008), however, it appears more likely that direct (education) subsidies are paid out to the skilled. These would - analogously to the intuition in Bovenberg and Jacobs (2005) and Schindler and Yang (2007) - ceteris paribus mitigate distortions in learning effort, caused by graduate taxation, and would transform risky labor income in deterministic transfers. The latter then exactly fits the insurance strategy in Eaton and Rosen (1980a). Subsidies are, ceteris paribus, the more likely the higher graduate taxation $t^{H}$ and the lower the overall tax burden on successful education are.

However, potential subsidies $f_{B}<0$ cannot be larger than graduate tax revenue collected from the skilled households, because it must be $B>0$ from

\footnotetext{
${ }^{15}$ This redistribution is conducted by additional tax payments of the skilled and is measured as the difference between the net social marginal valuation of income by the unskilled and the average net social marginal value of income in the society.
} 
Lemma 1. Unskilled workers, therefore, do not take part in income insurance of skilled workers, and there are still resources transferred from the skilled sector to the educational sector in order to provide enhanced quality of education.

Optimal public investment $E$ is obtained from rearranging FOC (31)

$$
E^{*}=p^{*} \cdot\left[\epsilon_{p E} \cdot \frac{V^{H}-V^{L}}{\lambda}+\left[t^{H} w_{H} \mathrm{E}\left[\theta_{i} \cdot H_{i}^{*}\right]+f_{B}\right]\left(\epsilon_{p E}+\epsilon_{p e} \cdot \eta_{e E}\right)\right]>0,
$$

whereat $\epsilon_{p E}=\frac{E}{p^{*}(e, E)} \cdot p_{E}^{*}>0$ is the elasticity of the success probability with respect to a change in public spending for (the quality of) the education system, $E$, and $\eta_{e E}=\frac{E}{e} \cdot \frac{\partial e}{\partial E}>0$ is the elasticity of learning effort with respect to the endowment of universities.

The second term on the RHS of equation (39) mirrors the increased importance of enhancing educational quality in a Second-best world. The call for public real investment in the educational sector, due to welfare gains of increasing the skilled population, is strengthened by positive net taxation of education, $B=t^{H} w_{H} \mathrm{E}\left[\theta_{i} \cdot H_{i}^{*}\right]+f_{B}>0$, having a negative substitution effect on learning effort, and therefore, decreasing the success probability. Hence, it is important to counter these distortions by increased public spending $E$.

Taken together the combination of graduate taxation and skill-specific tuition fees, $t^{H}$ and $f_{B}$, and public investment $E$ allow once more for insurance against educational (failure) risk and redistribution between skilled and unskilled workers at lower costs than a general wage tax - and imply that stabilizing quality of education plays an important role in a Second-best world.

Proposition 3. Optimal real investment in the educational sector $E^{*}>0$ exploits welfare gains from an increased share of skilled households and mitigates distortions in learning effort, which are caused by the tax instruments $t^{H}$ and ${ }_{B}^{f}$.

Thereby, the endowment of the educational sector $E^{*}$ and

(i) the skill premium $V^{H}-V^{L}$,

(ii) the graduate wage tax rate $t^{H}$,

(iii) and skill-specific tuition fees $f_{B}$ 
are strategic (fiscal) complements. Instead, marginal costs of tax revenue, $\lambda$, and public investment are strategic substitutes.

Closing the model, the optimal lump-sum transfer can be inferred from the governmental budget constraint, recognizing that in the optimum $t=0$. Accordingly,

$$
T=p^{*}\left\{t^{H} \cdot w_{H} \cdot \mathrm{E}\left[\theta_{i} \cdot H_{i}^{*}\right]+f_{B}\right\}-E .
$$

Applying equation (39) in (40), we infer

$$
T^{*}=\left(-p^{*}\right)\left[\epsilon_{p E} \frac{V^{H}-V^{L}}{\lambda}+\left(\epsilon_{p E}+\epsilon_{p e} \cdot \eta_{e E}-1\right)\left(t^{H} w_{H} \mathrm{E}\left[\theta_{i} H_{i}^{*}\right]+f_{B}\right)\right] .
$$

Consequently, we can state:

Proposition 4. Some part of public expenditure is financed by general tuition fees $T<0$, if the success probability for entering the skilled sector is sufficiently elastic. Sufficient conditions are:

(i) The success probability with respect to public spending is elastic, $\epsilon_{p E} \geq 1$, or

(ii) The combination of production and complementarity elasticities results in $\epsilon_{p E}+\epsilon_{p e} \cdot \eta_{e E}>1$.

Proof. Proposition 4 follows directly from (41) and recognizing that $V^{H}>V^{L}$ as well as $B=t^{H} \cdot w_{H} \cdot \mathrm{E}\left[\theta_{i} \cdot H_{i}^{*}\right]+f_{B}>0$ from Lemma 1 .

Proposition 4 reproduces the central result in Schindler and Weigert (2008) concerning direct income transfers to unskilled households. Given that the learning technology is not too inefficient - meaning the optimal success probability is not too inelastic - both skilled and unskilled workers have to pay for the educational sector by a uniform lump-sum tax, which can be interpreted as general tuition fees, being not insured via skill-specific tuition fees.

Summarizing all our results, wage risks in the skilled sector are insured and diversified only among the graduated by positive, labor supply distorting graduate (wage) taxation and by skill-specific tuition fees. The latter can turn negative in 
order to provide a deterministic income transfer. Hence, direct education subsidies for skilled workers, $f_{B}<0$, can be welfare maximizing. The unskilled sector is neither affected by technological change nor by its social insurance policy.

Redistribution between skilled and unskilled households and insurance against educational risk of failure at university are again provided by a combination of (a) skill-specific tuition fees respectively a graduate tax, which together ensure that the skilled pay more than the unskilled for the public educational investment, and (b) public real investment into the educational sector. The former, (a), follows at once from comparing the tax burdens of a skilled and an unskilled household: $t^{H} w_{H} \theta_{i} H_{i}^{*}+f_{B}-T>-T>0$. The latter, (b), is invested in order to stabilize and enhance the quality of education, i.e., the 'filter technology' by Konrad (2004), and to increase the expected utility of every household from an ex ante point of view.

Though there are distortions in skilled labor supply and though graduate and general wage taxation are equivalent with respect to effects on skilled labor supply, there is no trade-off between distortions in skilled and unskilled labor supply. The general wage tax is not used and the Lipsey-Lancaster theorem cannot be applied. This non-mitigation of distortions in labor supplies is very amazing, especially as it is not driven by production efficiency. The reason is that, first, a general wage tax is still inferior for insurance against the risk of failure and for redistribution between the sectors, as long as there are both public investment into the quality of the educational sector and tax instruments, being tailored to tax only the skilled, available. Second, insuring wage risk is a dichotomic task, which can be done sufficiently by combining graduate taxation and skill-specific tuition fees. Distorting unskilled labor supply would not create any additional insurance effect, but harm those part of the society, having the highest value in the social welfare function.

Last, but not least, quality of education matters again more than direct income insurance: we have general tuition fees (lump-sum taxes $T<0$ ), which have to be paid irrespectively of being successful or not, instead of direct income transfers to the unskilled. These resources are used in order to improve the likelihood of being successful - accordingly, for providing ex ante insurance.

Contrary to the case of deterministic wages, it can, however, happen (and it 
is very likely) that the "front-loaded" tuition fees get regressive. If the concern for insurance is (very) high and the compensated wage elasticity is sufficiently low in the skilled sector, graduate taxation becomes (very) high and skill-specific tuition fees turn negative. Therefore, we end up with direct subsidies $f_{B}<0$. Then, front-loaded fees are $-T>0$ for the unskilled and $f_{B}-T<-T$ for the skilled. Admittedly, this regression is more than compensated by back-loaded fees, namely graduate taxation, which simultaneously fulfills an income-insurance function. Put together, the net tax burden of skilled workers is still higher than the one of the unskilled ones.

The regression result in tuition fees can back education policies, observed in the real world: In the US, gifted students receive rebates in (or scholarships for) their tuition fees. In Germany, successful and fast students receive rebates in their fees or direct subsidies via financial student aid (BAföG), because their credit repayment obligations are decreased. Additionally, in both countries, there is at least some progressive labor taxation, implementing ex post tuition fees via higher marginal tax rates - according to our graduate taxation.

\section{Conclusions}

We examine the optimal tax and education policy to maximize social welfare in case of (endogenous) risk of failure in education, being determined via learning effort by the individuals, and of wage risk within the skilled sector, driven by technological change.

We show that insuring against these risks is a dichotomic task: wage risk in the skilled sector is diversified between all graduates by implementing a positive graduate tax and granting education subsidies by skill-specific tuition fees. The unskilled are not affected and their labor supply is not distorted by this task.

Insuring against educational risk of failure is implemented by an ex ante approach, focusing on quality of education. All households have to pay general tuition fees (a general lump sum tax). These resources plus the positive net revenue from graduate taxation are invested into the quality of the educational system. This increases the success probability of each student and thereby increases its expected utility - providing efficient insurance. 
Taken together, we end up with a graduate tax, mirroring progressive income taxation, but regressive tuition fees. Therefore, our results can provide a justification for real world tuition fee systems, where, e.g., in Germany, successful students pay less 'front-loaded' fees per semester than drop-outs, because they receive direct rebates in their tuition fees or subsidies by favorable repayment rules in student loans (i.e., BAföG). Nevertheless, these successful students still have higher net payments for their education received due to progressive (graduate) taxation.

\section{Appendix}

\section{Deriving Equation (32)}

Applying Steiner's rule, $\mathrm{E}[\tilde{x} \cdot \tilde{y}]=\mathrm{E}[\tilde{x}] \cdot \mathrm{E}[\tilde{y}]+\operatorname{Cov}(\tilde{x}, \tilde{y})$, in equation (30) and inserting equation (27) therein, allows to cancel the direct effects. Rearranging and dividing by $\lambda$ then results in

$$
\begin{aligned}
& p^{*} A \cdot \mathrm{E}\left[\frac{\partial\left(\theta_{i} \cdot H_{i}\right)}{\partial t^{H}}+w_{H} \mathrm{E}\left[\theta_{i} \cdot H_{i}^{*}\right] \cdot \frac{\partial\left(\theta_{i} \cdot H_{i}\right)}{\partial T}\right] \\
& -p^{*} w_{H} \cdot \frac{\operatorname{Cov}\left(\alpha^{H}, \theta_{i} H_{i}^{*}\right)}{\lambda}+B p_{e}^{*}\left[\frac{\partial e}{\partial t^{H}}-\frac{\partial e}{\partial f_{B}} \cdot w_{H} \mathrm{E}\left[\theta_{i} \cdot H_{i}^{*}\right]\right]=0 .
\end{aligned}
$$

Using the Slutsky decomposition and collecting income effects, we find for the first term in squared brackets on the LHS

$$
\frac{\partial\left(\theta_{i} \cdot H_{i}\right)}{\partial t^{H}}+w_{H} \mathrm{E}\left[\theta \cdot H_{i}^{*}\right] \cdot \frac{\partial\left(\theta_{i} \cdot H_{i}\right)}{\partial T}=-S_{H H} \cdot w_{H}
$$

in which $S_{H H}>0$ represents the pure substitution effect of a change in the wage rate $w_{H}$ onto effective skilled labor supply.

Moreover, recognizing the comparative static effects (17) and (15) and, again, Steiner's rule, the second term in squared brackets on the LHS turns out to be

$$
\frac{\partial e}{\partial t^{H}}-\frac{\partial e}{\partial f_{B}} \cdot w_{H} \mathrm{E}\left[\theta_{i} \cdot H_{i}^{*}\right]=\frac{p_{e}^{*} w_{H}}{S O C(e)} \cdot \operatorname{Cov}\left(\alpha^{H}, \theta_{i} H_{i}^{*}\right),
$$


by collecting terms. If we, furthermore, insert FOC (8) of the household into its corresponding SOC, equation (11), and rearrange, we obtain

$$
\begin{aligned}
\operatorname{SOC}(e) & =-p_{e}^{*}\left(V^{H}-V^{L}\right)\left(-\frac{U_{1 l_{1} l_{1}}}{U_{l_{1}}}-\frac{p_{e e}}{p_{e}}\right) \\
& =-p_{e}^{*}\left(V^{H}-V^{L}\right)\left[A R A(e)+h\left(p_{e}\right)\right],
\end{aligned}
$$

where $A R A(e)=-\frac{U_{1 l_{1} l_{1}}}{U_{l_{1}}}>0$ equals absolute risk aversion in first period leisure respectively learning effort, and where $h\left(p_{e}\right)=-\frac{p_{e e}}{p_{e}}>0$ as hazard rate determines, how fast marginal productivity of learning effort decreases.

Inserting then the terms (43) - (45) in equation (42), we receive

$p^{*} A \cdot \mathrm{E}\left[-S_{H H}\right] w_{H}=-\frac{B p_{e}^{*} w_{H}}{V^{H}-V^{L}} \frac{\operatorname{Cov}\left(\alpha^{H}, \theta_{i} H_{i}^{*}\right)}{A R A(e)+h\left(p_{e}\right)}-p^{*} w_{H} \cdot \frac{\operatorname{Cov}\left(\alpha^{H}, \theta_{i} H_{i}^{*}\right)}{\lambda}$.

Re-substituting $A=\left(t+t^{H}\right) \cdot w_{H}$ and interpreting $\xi(\theta)=-\frac{\operatorname{Cov}\left(\alpha^{H}, w_{H} \theta_{i} H_{i}^{*}\right)}{\bar{\alpha}^{H} \cdot w_{H} \cdot \mathrm{E}\left[\theta_{i} \cdot H_{i}^{*}\right]}>$ 0 as insurance characteristic in skilled labor income, rearranging and collecting terms provide equation (32) as

$$
\frac{t+t^{H}}{1-t-t^{H}}=\left[\frac{\bar{\alpha}^{H}}{V^{H}-V^{L}} \cdot \frac{h(p) \cdot B}{A R A(e)+h\left(p_{e}\right)}+\frac{\bar{\alpha}^{H}}{\lambda}\right] \cdot \frac{\xi(\theta)}{\epsilon_{H H}},
$$

where $\epsilon_{H H}=\frac{\left(1-t-t^{H}\right) w_{H}}{\mathrm{E}\left[\theta_{i} \cdot H_{i}^{*}\right]} \cdot \mathrm{E}\left[S_{H H}\right]>0$ and $h(p)=\frac{p_{e}}{p}$.

\section{Deriving Equation (33)}

Solving (27) for $p^{*} \cdot \bar{\alpha}^{H}$ and (30) for $p^{*} \mathrm{E}\left[\alpha^{H} \cdot w_{H} \theta_{i} H^{*}\right]$, respectively solving (28) for $\left(1-p^{*}\right) \cdot \alpha^{L}$, we can substitute these expressions into the first order condition (29). Then, all direct effects sum up to zero and canceling the Lagrangian parameter $\lambda$ delivers

$$
\begin{array}{r}
p^{*} A \mathrm{E}\left[-\frac{\partial\left(\theta_{i} \cdot H_{i}\right)}{\partial t^{H}}+w_{L} L^{*}\left(\frac{\partial\left(\theta_{i} \cdot H_{i}\right)}{\partial T}+\frac{\partial\left(\theta_{i} \cdot H_{i}\right)}{\partial f_{B}}\right)+\frac{\partial\left(\theta_{i} \cdot H_{i}\right)}{\partial t}\right] \\
+\left(1-p^{*}\right) t w_{L} \cdot\left[\frac{\partial L}{\partial t}+\frac{\partial L}{\partial T} w_{L} L^{*}\right] \\
=-B p_{e}^{*} \cdot\left[-\frac{\partial e}{\partial t^{H}}+\frac{\partial e}{\partial T} \cdot w_{L} L^{*}+w_{L} L^{*} \cdot \frac{\partial e}{\partial f_{B}}+\frac{\partial e}{\partial t}\right]
\end{array}
$$


For simplifying some expressions in (47), we can use $\frac{\partial H_{i}^{*}}{\partial t}=\frac{\partial H_{i}^{*}}{\partial t^{H}}$ from (12) and $\frac{\partial H_{i}^{*}}{\partial T}=-\frac{\partial H_{i}^{*}}{\partial f_{B}}$ from (13) as well as $\frac{\partial\left(\theta_{i} \cdot H_{i}^{*}\right)}{\partial a}=\theta_{i} \cdot \frac{\partial H_{i}^{*}}{\partial a} \forall a=t, t^{H}, T, f_{B}$, in order to obtain

$$
\mathrm{E}\left[\theta_{i} \cdot\left(-\frac{\partial H}{\partial t^{H}}+\frac{\partial H}{\partial T} \cdot w_{L} L^{*}+w_{L} L^{*} \cdot \frac{\partial H}{\partial f_{B}}+\frac{\partial H}{\partial t}\right)\right]=0
$$

for the first term in squared brackets.

Instead inserting the comparative static effects in learning effort, (14) - (15) and (17) - (18), into the third squared bracket in equation (47), this delivers

$$
-\frac{\partial e}{\partial t^{H}}+\frac{\partial e}{\partial T} \cdot w_{L} L^{*}+w_{L} L^{*} \cdot \frac{\partial e}{\partial f_{B}}+\frac{\partial e}{\partial t}=0 .
$$

When we now substitute (48) and (49) into (47) and apply the Slutsky decomposition for unskilled labor supply, income effects cancel out and we end up with equation (33) as

$$
\frac{t}{1-t} \cdot\left(1-p^{*}\right) \cdot w_{L} L^{*} \cdot \epsilon_{L L}=0
$$

where $\epsilon_{L L}=\frac{(1-t) w_{L}}{L^{*}} \cdot S_{L L}$.

\section{Proof of Lemma 1}

Applying $t=0$ from Proposition $1, B=t^{H} \cdot w_{H} \cdot \mathrm{E}\left[\theta_{i} \cdot H_{i}^{*}\right]+f_{B}$ represents the net tax burden on learning effort. In order to show that $B>0$, we use $t=0$ in FOCs (27) and (28) and add the two equations. Reverting to $\frac{\partial H_{i}^{*}}{\partial T}=-\frac{\partial H_{i}^{*}}{\partial f_{B}}$ from equation (13), this leads to

$$
\left(1-p^{*}\right)\left(\alpha^{L}-\lambda\right)=-\lambda B p_{e}^{*} \cdot\left[\frac{\partial e}{\partial f_{B}}+\frac{\partial e}{\partial T}\right]
$$

where $\frac{\partial e}{\partial f_{B}}+\frac{\partial e}{\partial T}<0$, because of comparative static results in (15) and (14).

From rearranging FOC (27), we have in case of $t=0$

$$
p^{*} \cdot\left(\bar{\alpha}^{H}-\lambda\right)=\lambda \cdot p^{*} \cdot t^{H} \cdot w_{h} \cdot \mathrm{E}\left[\frac{\partial\left(\theta_{i} \cdot H_{i}\right)}{\partial f_{B}}\right]+\lambda \cdot B \cdot p_{e}^{*} \cdot \frac{\partial e}{\partial f_{B}},
$$


where $p_{e}>0$ by assumption, $\frac{\partial\left(\theta_{i} \cdot H_{i}\right)}{\partial f_{B}}>0$ from (13) and $\frac{\partial e}{\partial f_{B}}<0$ from (15).

Assume now $B \leq 0$, then it must hold $\alpha^{L} \leq \lambda$ from (50) and $\bar{\alpha}^{H}>\lambda$ from (51). This then implies $\bar{\alpha}^{H}>\alpha^{L}$, which contradicts our assumption of agent monotonicity. Hence, $B \leq 0$ cannot appear in an optimum.

Only if $B>0$, there is support for $\alpha^{L}>\bar{\alpha}^{H}$. Furthermore, in this case it holds true from equation (50) that $\alpha^{L}>\lambda$.

\section{References}

AnderberG, D. (2008): "Optimal Policy and the Risk-Properties of Human Capital Reconsidered.” Royal Holloway University of London, mimeo.

AnderberG, D. And F. Andersson (2003): "Investments in Human Capital, Wage Uncertainty, and Public Policy,” Journal of Public Economics, 87, 15211537.

Andersson, F. And K. Konrad (2003a): “Globalization and Risky HumanCapital Investment," International Tax and Public Finance, 10, 211-228.

- (2003b): "Human Capital Investment and Globalization in Extortionary States," Journal of Public Economics, 87, 1539-1555.

BovenberG, A. L. AND B. JaCOBS (2005): "Redistribution and Education Subsidies are Siamese Twins," Journal of Public Economics, 89, 2005-2035.

Carneiro, P., K. T. Hansen, And J. J. Heckman (2003): “Estimating Distributions of Treatment Effects with an Application to the Returns to Schooling and Measurement of the Effects of Uncertainty on College Choice," International Economic Review, 44, 361-422.

DA Costa, C. E. And L. J. Maestri (2007): “The Risk Properties of Human Capital and the Design of Governmental Policies,' European Economic Review, 51, 695-713.

EATON, J. AND H. S. Rosen (1980a): "Labor Supply, Uncertainty, and Efficient Taxation,” Journal of Public Economics, 14, 365-374. 
(1980b): “Taxation, Human Capital, and Uncertainty," American Economic Review, 70, 705-715.

EU-CouncIL (2005): "Meeting of the European Council. Conclusions of the President," EU DOC-05-1.

FELDSTEIN, M. S. (1972): "Distributional Equity and the Optimal Structure of Public Prices,” American Economic Review, 62, 32-36.

GARCíA-PEÑAlosA, C. AND K. WÄLdE (2000): "Efficiency and Equity Effects of Subsidies to Higher Education," Oxford Economic Papers, 52, 702-722.

Glomm, G. And B. Ravikumar (1992): "Public versus Private Investment in Human Capital Endogenous Growth and Income Inequality," Journal of Political Economy, 100, 813-834.

Hamilton, J. H. (1987): "Optimal Wage and Income Taxation with Wage Uncertainty," International Economic Review, 28, 373-388.

JACOBS, B. (2002): "An Investigation of Education Finance Reform. Income Contingent Loans and Graduate Taxes in the Netherlands," CPB Discussion Paper No. 9, CPB Netherlands Bureau for Economic Policy Research, Den Haag.

- (2004): "The Lost Race between Schooling and Technology," DeEconomist, 152, 47-78.

Jacobs, B. And L. A. Bovenberg (2008): “Optimal Taxation of Human Capital and the Earnings Function," CESifo Working Paper No. 2250, Munich.

JACOBS, B. AND S. J. VAN WiJnBERGEN (2007): "Capital-Market Failure, Adverse Selection, and Equity Financing of Higher Education," FinanzArchiv, 63, forthcoming.

KATZ, L. F. AND D. H. Autor (1999): Changes in the Wage Structure and Earnings Inequality, Amsterdam: Elsevier Science, vol. 3, chap. 26, 14631555. 
KodDE, D. A. (1986): "Uncertainty and the Demand for Education," Review of Economics and Statistics, 68, 460-467.

(1988): "Unemployment Expectations and Human Capital Formation," European Economic Review, 32, 1645-1660.

KOnRAD, K. A. (2004): Mobilität in mehrstufigen Ausbildungsturnieren, Tübingen: Mohr Siebeck, vol. 33 of Wirtschaftswissenschaftliches Seminar Ottobeuren, 67-81.

Krugman, P. (1995): "Growing World Trade: Causes and Consequences," Brookings Papers on Economic Activity, 1, 327-377.

LEVHARI, D. AND Y. WeISS (1974): "The Effect of Risk on the Investment in Human Capital," American Economic Review, 64, 950-963.

Lipsey, R. G. And K. LANCASTER (1956): "The General Theory of Second Best," Review of Economic Studies, 24, 11-36.

Maldonado, D. (2008): "Education Policies and Optimal Taxation," International Tax and Public Finance, 15, 131-143.

Mincer, J. (1974): Schooling, Experience, and Earnings, Columbia University Press.

Mirrlees, J. A. (1976): “Optimal Tax Theory: A Synthesis," Journal of Public Economics, 6, 327-358.

OECD (2007): Education at a Glance 2007, Paris: OECD.

Schindler, D. AND B. WeIGERT (2008): "Insuring Educational Risk: Opportunities versus Income,” CESifo Working Paper Series No. 2348, Munich.

SCHINDleR, D. AND H. YANG (2007): "Risky Human Capital Formation Requires 'Siamese Twins',' Research Group Heterogenous Labor Discussion Paper 07/10, University of Konstanz, Konstanz.

SinN, H.-W. (1996): “Social Insurance, Incentives, and Risk-taking," International Tax and Public Finance, 3, 259-280. 
WigGer, B. U. AND R. VON WEIZSÄCKER (2001): "Risk, Resources, and Education - Public versus Private Financing of Higher Education," IMF Staff Papers, 48, 547-560.

Wildasin, D. E. (2000): "Labor-Market Integration, Investment in Risky Human Capital, and Fiscal Competition," American Economic Review, 90, 73-95. 


\section{CESifo Working Paper Series}

for full list see www.cesifo-group.org/wp

(address: Poschingerstr. 5, 81679 Munich, Germany, office@cesifo.de)

2449 Jan Bouckaert, Hans Degryse and Thomas Provoost, Enhancing Market Power by Reducing Switching Costs, November 2008

2450 Frank Heinemann, Escaping from a Combination of Liquidity Trap and Credit Crunch, November 2008

2451 Dan Anderberg, Optimal Policy and the Risk Properties of Human Capital Reconsidered, November 2008

2452 Christian Keuschnigg and Evelyn Ribi, Outsourcing, Unemployment and Welfare Policy, November 2008

2453 Bernd Theilen, Market Competition and Lower Tier Incentives, November 2008

2454 Ondřej Schneider, Voting in the European Union - Central Europe's Lost Voice, November 2008

2455 Oliver Lorz and Gerald Willmann, Enlargement versus Deepening: The Trade-off Facing Economic Unions, November 2008

2456 Alfons J. Weichenrieder and Helen Windischbauer, Thin-Capitalization Rules and Company Responses, Experience from German Legislation, November 2008

2457 Andreas Knabe and Steffen Rätzel, Scarring or Scaring? The Psychological Impact of Past Unemployment and Future Unemployment Risk, November 2008

2458 John Whalley and Sean Walsh, Bringing the Copenhagen Global Climate Change Negotiations to Conclusion, November 2008

2459 Daniel Mejía, The War on Illegal Drugs in Producer and Consumer Countries: A Simple Analytical Framework, November 2008

2460 Carola Frydman, Learning from the Past: Trends in Executive Compensation over the Twentieth Century, November 2008

2461 Wolfgang Ochel, The Political Economy of Two-tier Reforms of Employment Protection in Europe, November 2008

2462 Peter Egger and Doina Maria Radulescu, The Influence of Labor Taxes on the Migration of Skilled Workers, November 2008

2463 Oliver Falck, Stephan Heblich and Stefan Kipar, The Extension of Clusters: Differencein-Differences Evidence from the Bavarian State-Wide Cluster Policy, November 2008 
2464 Lei Yang and Keith E. Maskus, Intellectual Property Rights, Technology Transfer and Exports in Developing Countries, November 2008

2465 Claudia M. Buch, The Great Risk Shift? Income Volatility in an International Perspective, November 2008

2466 Walter H. Fisher and Ben J. Heijdra, Growth and the Ageing Joneses, November 2008

2467 Louis Eeckhoudt, Harris Schlesinger and Ilia Tsetlin, Apportioning of Risks via Stochastic Dominance, November 2008

2468 Elin Halvorsen and Thor O. Thoresen, Parents' Desire to Make Equal Inter Vivos Transfers, November 2008

2469 Anna Montén and Marcel Thum, Ageing Municipalities, Gerontocracy and Fiscal Competition, November 2008

2470 Volker Meier and Matthias Wrede, Reducing the Excess Burden of Subsidizing the Stork: Joint Taxation, Individual Taxation, and Family Splitting, November 2008

2471 Gunther Schnabl and Christina Ziegler, Exchange Rate Regime and Wage Determination in Central and Eastern Europe, November 2008

2472 Kjell Erik Lommerud and Odd Rune Straume, Employment Protection versus Flexicurity: On Technology Adoption in Unionised Firms, November 2008

2473 Lukas Menkhoff, High-Frequency Analysis of Foreign Exchange Interventions: What do we learn?, November 2008

2474 Steven Poelhekke and Frederick van der Ploeg, Growth, Foreign Direct Investment and Urban Concentrations: Unbundling Spatial Lags, November 2008

2475 Helge Berger and Volker Nitsch, Gotcha! A Profile of Smuggling in International Trade, November 2008

2476 Robert Dur and Joeri Sol, Social Interaction, Co-Worker Altruism, and Incentives, November 2008

2477 Gaëtan Nicodème, Corporate Income Tax and Economic Distortions, November 2008

2478 Martin Jacob, Rainer Niemann and Martin Weiss, The Rich Demystified - A Reply to Bach, Corneo, and Steiner (2008), November 2008

2479 Scott Alan Carson, Demographic, Residential, and Socioeconomic Effects on the Distribution of $19^{\text {th }}$ Century African-American Stature, November 2008

2480 Burkhard Heer and Andreas Irmen, Population, Pensions, and Endogenous Economic Growth, November 2008 
2481 Thomas Aronsson and Erkki Koskela, Optimal Redistributive Taxation and Provision of Public Input Goods in an Economy with Outsourcing and Unemployment, December 2008

2482 Stanley L. Winer, George Tridimas and Walter Hettich, Social Welfare and Coercion in Public Finance, December 2008

2483 Bruno S. Frey and Benno Torgler, Politicians: Be Killed or Survive, December 2008

2484 Thiess Buettner, Nadine Riedel and Marco Runkel, Strategic Consolidation under Formula Apportionment, December 2008

2485 Irani Arraiz, David M. Drukker, Harry H. Kelejian and Ingmar R. Prucha, A Spatial Cliff-Ord-type Model with Heteroskedastic Innovations: Small and Large Sample Results, December 2008

2486 Oliver Falck, Michael Fritsch and Stephan Heblich, The Apple doesn't Fall far from the Tree: Location of Start-Ups Relative to Incumbents, December 2008

2487 Cary Deck and Harris Schlesinger, Exploring Higher-Order Risk Effects, December 2008

2488 Michael Kaganovich and Volker Meier, Social Security Systems, Human Capital, and Growth in a Small Open Economy, December 2008

2489 Mikael Elinder, Henrik Jordahl and Panu Poutvaara, Selfish and Prospective: Theory and Evidence of Pocketbook Voting, December 2008

2490 Maarten Bosker and Harry Garretsen, Economic Geography and Economic Development in Sub-Saharan Africa, December 2008

2491 Urs Fischbacher and Simon Gächter, Social Preferences, Beliefs, and the Dynamics of Free Riding in Public Good Experiments, December 2008

2492 Michael Hoel, Bush Meets Hotelling: Effects of Improved Renewable Energy Technology on Greenhouse Gas Emissions, December 2008

2493 Christian Bruns and Oliver Himmler, It's the Media, Stupid - How Media Activity Shapes Public Spending, December 2008

2494 Andreas Knabe and Ronnie Schöb, Minimum Wages and their Alternatives: A Critical Assessment, December 2008

2495 Sascha O. Becker, Peter H. Egger, Maximilian von Ehrlich and Robert Fenge, Going NUTS: The Effect of EU Structural Funds on Regional Performance, December 2008

2496 Robert Dur, Gift Exchange in the Workplace: Money or Attention?, December 2008

2497 Scott Alan Carson, Nineteenth Century Black and White US Statures: The Primary Sources of Vitamin D and their Relationship with Height, December 2008 
2498 Thomas Crossley and Mario Jametti, Pension Benefit Insurance and Pension Plan Portfolio Choice, December 2008

2499 Sebastian Hauptmeier, Ferdinand Mittermaier and Johannes Rincke Fiscal Competition over Taxes and Public Inputs: Theory and Evidence, December 2008

2500 Dirk Niepelt, Debt Maturity without Commitment, December 2008

2501 Andrew Clark, Andreas Knabe and Steffen Rätzel, Boon or Bane? Others' Unemployment, Well-being and Job Insecurity, December 2008

2502 Lukas Menkhoff, Rafael R. Rebitzky and Michael Schröder, Heterogeneity in Exchange Rate Expectations: Evidence on the Chartist-Fundamentalist Approach, December 2008

2503 Salvador Barrios, Harry Huizinga, Luc Laeven and Gaëtan Nicodème, International Taxation and Multinational Firm Location Decisions, December 2008

2504 Andreas Irmen, Cross-Country Income Differences and Technology Diffusion in a Competitive World, December 2008

2505 Wenan Fei, Claude Fluet and Harris Schlesinger, Uncertain Bequest Needs and LongTerm Insurance Contracts, December 2008

2506 Wido Geis, Silke Uebelmesser and Martin Werding, How do Migrants Choose their Destination Country? An Analysis of Institutional Determinants, December 2008

2507 Hiroyuki Kasahara and Katsumi Shimotsu, Sequential Estimation of Structural Models with a Fixed Point Constraint, December 2008

2508 Barbara Hofmann, Work Incentives? Ex Post Effects of Unemployment Insurance Sanctions - Evidence from West Germany, December 2008

2509 Louis Hotte and Stanley L. Winer, The Demands for Environmental Regulation and for Trade in the Presence of Private Mitigation, December 2008

2510 Konstantinos Angelopoulos, Jim Malley and Apostolis Philippopoulos, Welfare Implications of Public Education Spending Rules, December 2008

2511 Robert Orlowski and Regina T. Riphahn, The East German Wage Structure after Transition, December 2008

2512 Michel Beine, Frédéric Docquier and Maurice Schiff, International Migration, Transfers of Norms and Home Country Fertility, December 2008

2513 Dirk Schindler and Benjamin Weigert, Educational and Wage Risk: Social Insurance vs. Quality of Education, December 2008 